\title{
Prey base shifts in red rock lobster Jasus edwardsii in response to habitat conversion in Fiordland marine reserves: implications for effective spatial management
}

\author{
Lucy Jack*', Stephen R. Wing, Rebecca J. McLeod \\ Department of Marine Science, University of Otago, PO Box 56, Dunedin, New Zealand
}

\begin{abstract}
Persistence of subpopulations dispersed among spatial management units, such as marine reserves, relies heavily upon the quality of local habitat, as well as size and connectivity of habitat patches. We examined the relative abundance of the red rock lobster Jasus edwardsii and its primary bivalve food resources within 3 marine reserves in the Doubtful-Bradshaw Sound complex in Fiordland, New Zealand. We used stable isotope analysis $\left(\delta^{13} \mathrm{C}, \delta^{15} \mathrm{~N}\right.$ and $\left.\delta^{34} \mathrm{~S}\right)$ to resolve differences in the carbon sources to food webs supporting $J$. edwardsii inhabiting these regions. Furthermore, we examined patterns in the relative concentration and $\delta^{13} \mathrm{C}$ signature of specific fatty acid biomarkers as an independent test of the carbon sources to each population. We found distinctive patterns in the relative abundance of red rock lobsters, with significantly more animals in the marine reserves at Te Awaatu Channel and Kutu Parera than in the surrounding open fishing areas and within the reserve at Taipari Roa. Taipari Roa Reserve is distinctive in that bivalve abundance is extremely low due to freshwater input from the Manapouri hydroelectric power plant. Analysis of $\delta^{13} \mathrm{C}, \delta^{15} \mathrm{~N}$ and $\delta^{34} \mathrm{~S}$ of red rock lobster muscle tissue as well as $\delta^{13} \mathrm{C}$ of $16: 1 \omega 7$ and $18: 1 \omega 7$ indicated that, in those areas where heterotrophic bivalves are rare, red rock lobsters rely more on recycled carbon made available by chemoautotrophs. These findings suggest that efficacy of the new marine reserves is influenced by habitat quality in terms of the availability and abundance of food resources for red rock lobsters. We highlight the importance of considering habitat quality for effective implementation of marine reserves.
\end{abstract}

KEY WORDS: Fatty acid biomarker - Fiordland · Food web · Habitat quality · Marine reserve · Stable isotope

\section{INTRODUCTION}

Ecosystem-based resource management is a means of controlling anthropogenic impacts, in order to maintain biological diversity or restore it to its natural state. Marine protected areas, in particular no-take reserves, are becoming a frequently implemented spatial management tool for conserving marine resources (Quinn et al. 1993, Palumbi 2001). This shift in management strategy follows empirical studies that demonstrate the dramatic responses of some species to local exclusion of fishing pressure (NRC 2001, Roberts et al. 2001, Halpern 2003). Marine reserves have been demonstrated to protect a portion of the spawning population from over harvesting and to conserve local biological diversity from the indirect effects of fishing (Bohnsack 1996, McClanahan \& Mangi 2000, Shears \& Babcock 2002), but their effectiveness may be strongly influenced by external forcing on habitat quality (Allison et al. 1998). The challenge remains for ecologists to offer insight for managers into the practical questions of 'where' and 'how much' by identifying key issues that 
should be considered when implementing new reserves or testing the efficacy of old ones, in particular those issues that are applicable across a broad range of systems (Roberts et al. 2003). The present study provides an example of the importance of habitat quality, and ecosystem function in terms of food web structure, for effective spatial management in coastal marine systems.

The importance of understanding the spatial structure of populations has been highlighted by studies that demonstrate the interactions between the life history of individual species and physical transport mechanisms that determine connectivity across regions, or the ability for some populations to self-seed within reserves (Botsford et al. 2001, Warner \& Cowen 2002, Almany et al. 2007). Consequently, application of spatial management in coastal systems can be improved with an understanding of how populations are connected across fragmented landscapes (Forgarty 1998, Cowen et al. 2000, Thorrold et al. 2001).

Metapopulations, subdivided populations connected by dispersal, can be subject to sudden collapse caused by environmental degradation or exploitation that pushes the total population below a persistence threshold (Hanski \& Gaggiotti 2004). Consequently, much of the theoretical inquiry into metapopulation dynamics has been focused on the interacting effects of patch size and connectivity on regional population persistence (MacArthur \& Wilson 1967, Hanski \& Gyllenberg 1993). Nevertheless, empirical studies across a wide variety of systems have also emphasized the importance of habitat quality for driving metapopulation dynamics and persistence (Root 1998, Franklin et al. 2000, Joy \& Death 2001, Lindholm et al. 2001, Fleishman et al. 2002, Jeffries 2005). Variability in quality among habitat patches can enhance reproductive source-sink structure across the regional population, making it more reliant on a smaller subset population for reproduction (Wing et al. 2003, Sanford \& Menge 2007). This effect is most pronounced in marine systems that have a fragmented habitat structure with strong environmental forcing on productivity patterns (Wing et al. 2008). Marine reserves containing high quality habitat are therefore more likely to sustain high rates of recovery from fishing pressure, as well as high eventual biomass or biodiversity (Fogarty 1999, Rodwell et al. 2003).

The marine region of Fiordland, New Zealand is made up of an insular, fragmented array of habitats within a physical environment containing extremes of salinity, wave action and irradiance that together influence patterns in productivity (Goebel et al. 2005, Wing et al. 2007). Evidence for the fragmented nature of populations and communities across the region is found in genetic studies (Sköld et al. 2003, Perrin et al.
2004) and in descriptions of the variability in community diversity across the landscape (Francis et al. 1989, Smith 2001). Studies of population structure in species such as blue cod Parapercis colias (Rodgers \& Wing 2008) and the New Zealand sea urchin Evechinus chloroticus (Lamare 1998, Wing et al. 2003) indicate that, for some species, the inner-fjord habitats support relatively isolated subpopulations linked by some dispersal from the outer coast. This type of population structure is particularly sensitive to harvest pressure, since harvesting of source populations in the most productive areas (in this case the outer coast) can affect a larger area through reductions in recruitment or adult dispersal. This situation has direct implications for effective spatial management in Fiordland (Rodgers \& Wing 2008, Wing in press).

Though relatively remote, Fiordland is also not immune from the effects of habitat conversion. For example, physical habitat and community structure have changed significantly in the inner reaches of Doubtful Sound as a consequence of the input of freshwater from the Manapouri power station (Batham 1965, Boyle et al. 2001, Tallis et al. 2004, Rutger \& Wing 2006). Populations of filter-feeding bivalves in this region are severely depleted due to extended exposure to freshwater (Rutger \& Wing 2006, McLeod \& Wing 2008). This depletion of bivalves, including mussels, has potentially severe implications locally for the flux of organic matter and benthic-pelagic coupling, as well as for species such as the red rock lobster Jasus edwardsii, which prey on bivalves (Witman \& Grange 1998).

In 1993, the 87 ha Te Awaatu Channel marine reserve was established in partially wave-sheltered habitat at the entrance of Doubtful Sound. More recently, the Fiordland Marine Management Act 2005 closed commercial fishing within the fjords (11363.7 ha Fiordland-wide) and established 8 new marine reserves in Fiordland, including the 426.4 ha Kutu Parera Reserve in Bradshaw Sound and the 610.8 ha Taipari Roa Reserve in inner Doubtful Sound (Fig. 1). These 2 reserves are situated in sheltered inner-fjord habitat, and all 3 reserves are nested within the new commercial exclusion zone (CEZ). Closures to fishing, either partially as in the case of the CEZs or wholly as in the marine reserves, will likely have areaspecific effects on local populations of exploited species. For this reason it is particularly important to consider biological responses to these management changes in the context of the local physical environment, local habitat quality and food resources within food webs.

We use Jasus edwardsii as an example of an exploited species likely to benefit from the implementation of marine reserves (Pande et al. 2008) and of an important higher trophic level predator on New Zea- 


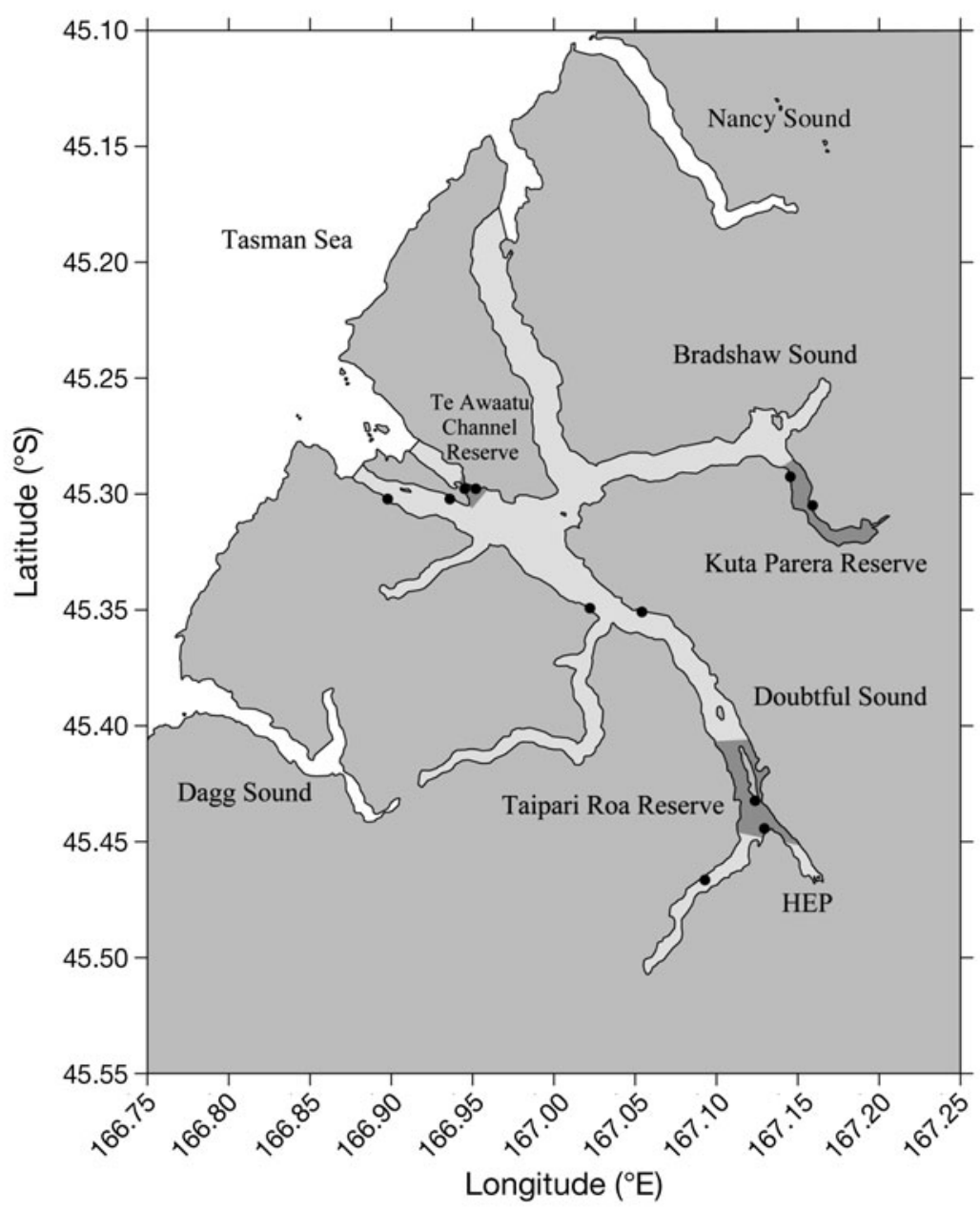

Fig. 1. Doubtful Sound region of Fiordland. (•) Locations of study sites. The commercial exclusion zone is depicted in light grey and the 3 marine reserves in dark gray. HEP marks the outlet of the Manapouri hydroelectric power plant

land rocky reefs (Shears \& Babcock 2002, Langlois et al. 2005). By removing all fishing, the new marine reserves likely reduce mortality and increase the potential for recovery in populations of $J$. edwardsii that have suffered localized depletion in the inner fjords (Annala 1983). J. edwardsii take 4 to 5 yr to reach sexual maturity and 5 to $7 \mathrm{yr}$ to reach harvestable size (MacDiarmid 1991). These moderate rates of growth and sexual maturation indicate that recovery of local populations from recruitment is likely to be gradual. Nevertheless, subsidies into suitable habitat, in the form of adult individuals migrating from the outer coast, may dramatically increase the rate of recovery of local populations and population changes within the new marine reserves.

In the present study, we evaluated the relative abundance of Jasus edwardsii in 3 marine reserves in the Doubtful-Bradshaw Sound complex and at comparable sites in the CEZ. As mussel beds are an important food resource for red rock lobsters in Fiordland (Witman \& Grange 1998), we then measured the relative abundance of this bivalve prey group at these sites. We used analyses of stable isotopes $\left(\delta^{13} \mathrm{C}, \delta^{15} \mathrm{~N}\right.$ and $\left.\delta^{34} \mathrm{~S}\right)$ of red rock lobster muscle tissue and $\delta^{13} \mathrm{C}$ of specific fatty acids (FAs) to measure the dietary contribution of the primary sources of organic matter (forest litter, chemoautotrophic bacterial symbionts, macroalgae and phytoplankton) to food webs supporting red rock lobsters in the 3 marine reserves. These analyses provided a way to quantify differences in diet that result from the effects of habitat conversion on food web structure and their likely influences on the efficacy of marine reserves in the Doubtful-Bradshaw Sound complex.

\section{MATERIALS AND METHODS}

Red rock lobster abundance surveys. Red rock lobster densities were recorded by visual underwater census at 11 sites in the DoubtfulBradshaw Sound complex. Two sites were located in each of the 3 marine reserves, and a series of 5 sites was distributed along the fjord axis in the CEZ (Fig. 1). Care was taken to survey comparable rock wall habitat, each site being on a slope of $>45^{\circ}$ and with abundant crevices and ledges offering suitable red rock lobster shelter. In the case of the 5 sites in the CEZ, site placement was distributed to sample across the primary environmental gradients of wave exposure and surface salinity (Wing et al. 2007). Belt transects measuring $50 \times 10 \mathrm{~m}$ were placed along rock walls at $15 \mathrm{~m}$ depth. Transects were initially placed randomly and then revisited at subsequent sampling events. Caves and crevices were thoroughly searched using a dive light. Sampling events $(n=6)$ took place at seasonal intervals during 2006 and 2007, and the number of transects at each site varied between sampling events ( $\mathrm{n}=1$ to 4 ). Following $\ln (x+1)$ transformation to increase normality and homogeneity of variance, variability in abundance between sampling events was tested using a nested ANOVA, with sample event nested within site. As no significant differences were detected between sampling events, data were pooled across time for further analysis. Variability in abundance across space was analyzed using a nested ANOVA, with site nested within management zone. A Tukey's post hoc test was used to test for differences between pairwise comparisons.

Mussel abundance surveys. We characterized the relative abundance of heterotrophic epibenthic bi- 
valve prey using a photoquadrat survey at each of the rocky reef sites in November 2007. Percentage cover of Mytilus edulis galloprovincialis and the less common mussels Perna canaliculus and Auclacomya maoriana was calculated as an index of their combined abundance. At each site, 25 photoquadrats using a $0.17 \mathrm{~m}^{2}$ framer and a Nikon D200 camera with a $12 \mathrm{~mm}$ lens were randomly distributed in the mussel band (0 to $5 \mathrm{~m}$ ), within the low salinity layer. Digital photos were imported into Image J (US National Institutes of Health) and percentage cover of mussels was calculated for each image. Site averages were calculated and abundance was presented in terms of percentage cover and standard error between quadrats. In the absence of a transformation that achieved nearnormality, non-parametric Wilcoxon/Kruskal-Wallis tests were used, followed by non-parametric multiple comparisons tests to resolve pairwise differences in percentage cover between regions.

Red rock lobster resource use determined by stable isotope analysis. In November 2004, 7 lobsters from outer Doubtful Sound and 16 from inner Doubtful Sound were sampled for analysis of stable isotope ratios of sulfur $\left(\delta^{34} \mathrm{~S}\right)$. In January 2006, 6 lobsters were sampled from each of the 11 study sites for analysis of stable isotope ratios of carbon $\left(\delta^{13} \mathrm{C}\right)$ and nitrogen $\left(\delta^{15} \mathrm{~N}\right)$. In this 2 nd analysis, samples from inner Doubtful Sound CEZ and reserve sites were combined because of low availability within the Taipari Roa Reserve. Lobsters were non-lethally sampled using the autonomic limb severance response to remove 1 hind limb per animal. Leg muscle was dried at $60^{\circ} \mathrm{C}$ and homogenized to a fine powder with a mortar and pestle.

Stable isotopes were analyzed by Iso-trace New Zealand. Samples were analyzed for $\delta^{13} \mathrm{C}, \delta^{15} \mathrm{~N}$ and $\delta^{34} \mathrm{~S}$ on a Europa 20-20 update stable isotope mass spectrometer (Europa Scientific) interfaced to a Carlo Erba elemental analyzer (NA1500, Carlo Erba) in continuous flow mode (precision: $0.2 \%$ for $\delta^{13} \mathrm{C}, 0.3 \%$ for $\delta^{15} \mathrm{~N}$ and $0.5 \%$ for $\delta^{34} \mathrm{~S}$ ). Analysis was calibrated to an EDTA laboratory standard reference (Elemental Microanalysis) and standardized against international standards (IAEACH-6 for carbon; IAEAN1 and IAEAN2 for nitrogen). Results are expressed in the standard delta notation (e.g. Peterson \& Fry 1987) where, for example, $\delta^{13} \mathrm{C}=\left[\left(\mathrm{R}_{\mathrm{smpl}} / \mathrm{R}_{\mathrm{std}}\right)-1\right] \times 1000$, where $\mathrm{R}_{\text {smpl }}={ }^{13} \mathrm{C} /{ }^{12} \mathrm{C}$ and $\mathrm{R}_{\text {std }}={ }^{13} \mathrm{C} /{ }^{12} \mathrm{C}$ of Peedee belemnite limestone. The primary standards for $\delta^{15} \mathrm{~N}$ and $\delta^{34} \mathrm{~S}$ were atmospheric nitrogen and the Diablo Canyon meteorite, respectively.

Isotopic mixing models. We used $\delta^{15} \mathrm{~N}$ and $\delta^{13} \mathrm{C}$ and the multiple source mixing model 'Isoerror' (Phillips \& Gregg 2001) to estimate the contribution to the lobster diet of the 3 primary carbon sources: (1) macroalgae,
(2) suspended particulate organic matter (SPOM) and (3) the combination of forest litter and chemoautotrophs. On the basis of the results of the 1st model, we then used $\delta^{34} \mathrm{~S}$ and $\delta^{13} \mathrm{C}$ in Isoerror to resolve the contribution of (1) forest litter, (2) chemoautotrophs and (3) the combination of SPOM and macroalgae to lobster diet for the inner Doubtful Sound site. In this 2nd analysis we used results from the 1st mixing model to normalize a combined SPOM-macroalgal signature, based on the relative contributions of these 2 source pools to the diet of lobsters in inner Doubtful Sound. We used mean values of $\delta^{15} \mathrm{~N}, \delta^{13} \mathrm{C}$ and $\delta^{34} \mathrm{~S}$ for forest litter, chemoautotrophs, macroalgae and SPOM collected from previous studies in the system (Lusseau \& Wing 2006, McLeod \& Wing 2007), with 2 trophic levels of enrichment. We used species- and tissue-specific values for incremental trophic enrichment of $\delta^{13} \mathrm{C}$ $\left(+0.84 \%\right.$ ) and $\delta^{15} \mathrm{~N}(+3.28 \%$ ) for Jasus edwardsii (Suring \& Wing 2009). For $\delta^{34} \mathrm{~S}$ we used average values $(+0.4 \%$ ) for trophic enrichment from McCutchan et al. (2003).

FA concentration and $\boldsymbol{\delta}^{\mathbf{1 3}} \mathbf{C}$. Lipid was extracted from $\sim 20 \mathrm{mg}$ subsamples of dried homogenized Jasus edwardsii muscle tissue $(\mathrm{n}=3$ each from inner Doubtful Sound and Te Awaatu Channel, n = 2 from Kuta Parera Reserve) by a modified procedure (detailed in Bligh \& Dyer 1959). FAs were then methylated after the method of McLeod \& Wing (2007). FA composition was determined by gas chromatography (GC) mass spectrometry (MS) on a 6890N Network GC System (Agilent Technologies) equipped with a 5975B inert XL EI/CI MS (Agilent Technologies). FA methyl esters (FAMEs) were separated on a ZB Wax Plus capillary column with a $30 \mathrm{~m} \times 0.25 \mathrm{~mm}$ inner diameter and $0.25 \mu \mathrm{m}$ film (Phenomenex). The column oven temperature was ramped from 120 to $250^{\circ} \mathrm{C}$ at $8^{\circ} \mathrm{C} \mathrm{min}{ }^{-1}$ and then held at this temperature for $9 \mathrm{~min}$. This method was found to achieve the best separation of the target compounds (16C to $20 \mathrm{C}$ chain length). FA peaks were identified by retention time matching with composite standards (PUFA No. 1, Supelco 37 component FAME mix, Sigma-Aldrich) and confirmed using the MS. The percentage of total fatty acids for target compounds (relative concentration) was calculated. FA notation describes the carbon chain length, followed by a colon and the number of double bonds. The position of the 1 st double bond is specified from the methyl end $(\omega)$, with all subsequent bonds methylene interrupted.

FAMEs were analyzed on a Thermo Trace GC ultra coupled with a Thermo DeltaplusXP isotope ratio MS. We injected $1 \mu \mathrm{l}$ of sample with a split/splitless injector at $300^{\circ} \mathrm{C}$. Separation was achieved using the capillary column described above with a helium flow of $1.8 \mathrm{ml}$ $\mathrm{min}^{-1}$. The GC oven temperature was ramped from 125 to $260^{\circ} \mathrm{C}$ at a rate of $4^{\circ} \mathrm{C} \mathrm{min}^{-1}$ and held at $260^{\circ} \mathrm{C}$ for 
7 min. FAMEs were combusted online in a microcombustion (Pt/Ni/Cu catalyzed) furnace at $940^{\circ} \mathrm{C}$ before being transferred to the isotope ratio MS for analysis. A precision of $\pm 0.4 \%$ was achieved. FA peaks were identified by retention time matching as described previously. $\delta^{13} \mathrm{C}$ values were standardized against multiple pulses of reference gas, and mass balance equations accounted for methanol added during methylation.

\section{RESULTS}

\section{Red rock lobster abundance surveys}

There were significant differences in abundance of Jasus edwardsii between management zones. A Tukey's post hoc test revealed that at Te Awaatu Channel, lobster density was significantly higher than in the other regions and that density was lower at Taipari Roa Reserve than at Kuta Parera Reserve $\left(F_{10,91}=16.8, \mathrm{r}^{2}=\right.$ 0.47, p < 0.0001, Tukey's test: Te Awaatu Channel (a), Kuta Parera Reserve (b), CEZ (bc), Taipari Roa Reserve (c); Fig. 2A).

\section{Bivalve abundance patterns}

The results of non-parametric Wilcoxon/KruskalWallis tests and non-parametric multiple comparisons tests indicated significant differences in percentage cover of mussels between sites $\left(\chi^{2}=88.89\right.$, df $=3, \mathrm{p}<$ 0.0001, Tukey's test: Te Awaatu Channel (a), Kuta Parera Reserve (ab), CEZ (b), Taipari Roa Reserve (c); Fig. 2B).

\section{Red rock lobster resource use determined by stable isotope analysis}

Analysis of $\delta^{13} \mathrm{C}$ and $\delta^{15} \mathrm{~N}$ for Jasus edwardsii from Te Awaatu Channel, Kuta Parera Reserve and inner Doubtful Sound sites relative to isotopic signatures of primary carbon sources (forest litter and chemoautotrophs, SPOM and macroalgae) indicated a significant depletion of ${ }^{15} \mathrm{~N}$ and ${ }^{13} \mathrm{C}$ in the samples of lobster muscle tissue collected from inner Doubtful Sound $\left(\delta^{15} \mathrm{~N} F_{2,47}=11.69, \mathrm{p}<0.0001\right.$, Tukey's test: Te Awaatu Channel (a), Kuta Parera Reserve (a), Taipari Roa Reserve (b); $\delta^{13} \mathrm{C} F_{2,47}=31.21, \mathrm{p}<0.0001$, Tukey's test: Te Awaatu Channel (a), Kuta Parera Reserve (a), Taipari Roa Reserve (b); Fig. 3A). Analysis of $\delta^{34}$ S from lobster muscle tissue collected from entrance sites and from inner Doubtful Sound indicated a significant depletion in ${ }^{34} \mathrm{~S}$ for lobsters inhabiting inner Doubtful Sound $\left(\delta^{34} \mathrm{~S}_{,} F_{1,21}=347.02, \mathrm{p}<0.0001\right.$; Fig. $\left.4 \mathrm{~A}\right)$.

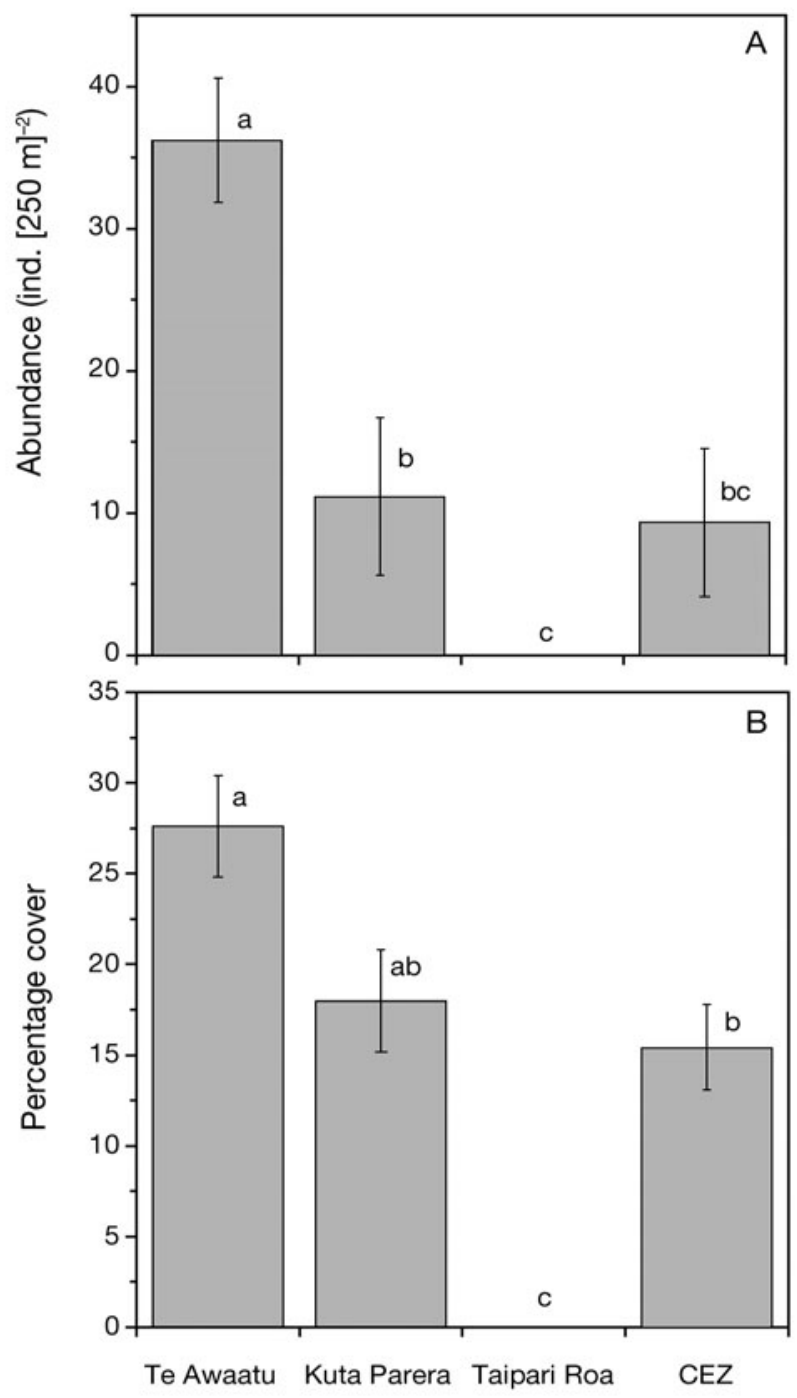

Fig. 2. Relative abundances of (A) red rock lobsters Jasus edwardsii and (B) mussels (predominately Mytilus edulis galloprovincialis) from Te Awaatu Channel, Kuta Parera Reserve, Taipari Roa Reserve and commercial exclusion zone (CEZ) sites (stratified along fjord axis). Error bars indicate $1 \mathrm{SE}$. Levels not connected by the same letter are significantly different

\section{Isotopic mixing models}

Results from the Isoerror mixing model using $\delta^{13} \mathrm{C}$ and $\delta^{15} \mathrm{~N}$ from samples of Jasus edwardsii from Te Awaatu Channel, Kuta Parera Reserve and the combined samples from inner Doubtful Sound showed a high contribution of carbon from macroalgae to red rock lobsters in all 3 regions (Fig. 3B). Input of carbon from SPOM was lower in the Taipari Roa Reserve/ inner Doubtful Sound samples, where input of carbon from a combination of forest litter and chemoautotrophs made up a substantial portion of the diet (Fig. 3B). Results of the Isoerror mixing model using 

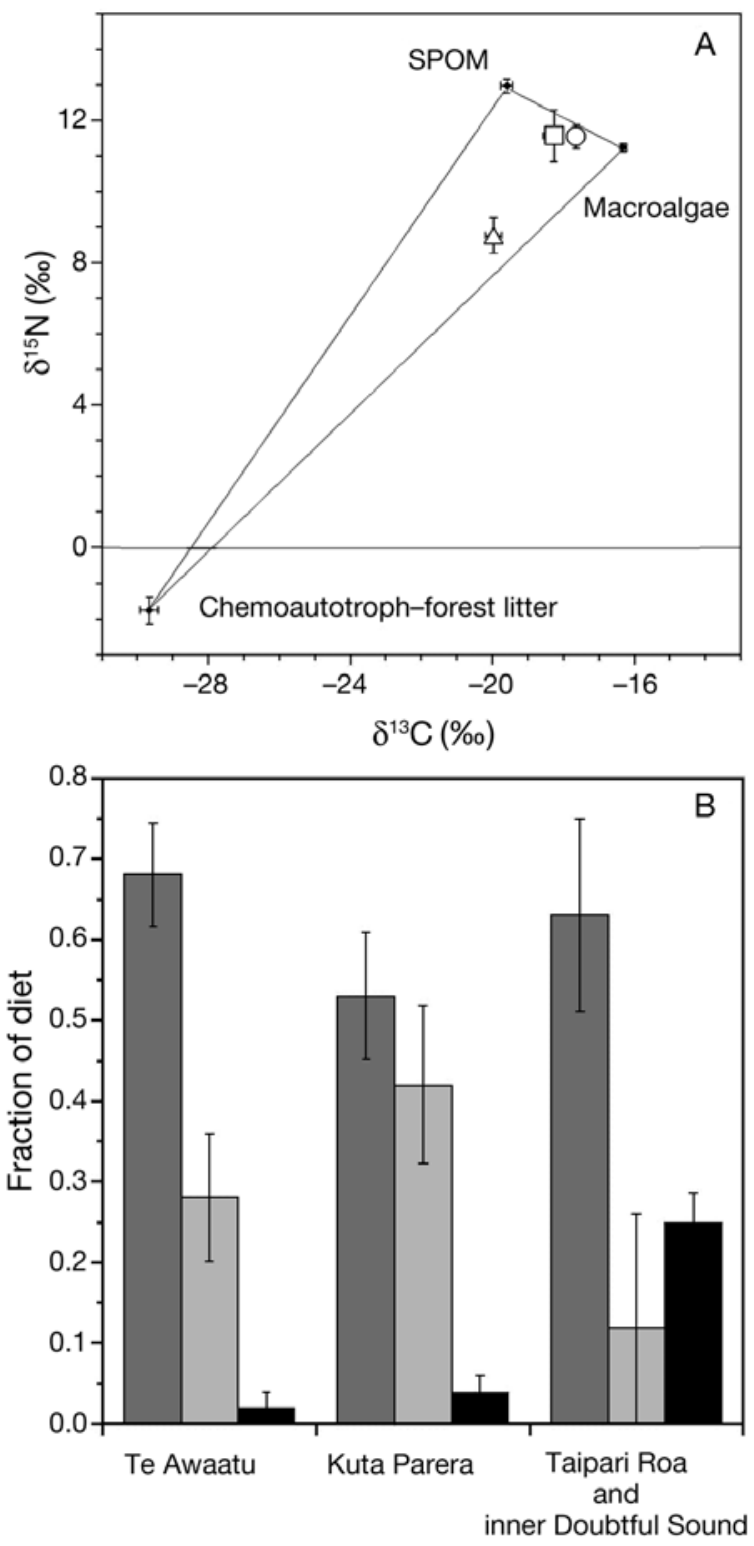

Fig. 3. Jasus edwardsii. (A) $\delta^{13} \mathrm{C}$ and $\delta^{15} \mathrm{~N}$ for red rock lobsters from Te Awaatu Channel (O) Taipari Roa Reserve and inner Doubtful Sound $(\Delta)$ and Kuta Parera Reserve ( $\square)$, and for primary carbon sources $(\bullet)$ (chemoautotroph-forest litter, suspended particulate organic matter [SPOM] and macroalgae) showing mean and SE. (B) Relative proportions of carbon sources (chemoautotroph-forest litter [black bars], SPOM [light grey bars] and macroalgae [dark grey bars]) used by lobsters from Te Awaatu Channel, Taipari Roa Reserve and Kuta Parera Reserve from the Isoerror mixing model using $\delta^{13} \mathrm{C}$ and $\delta^{15} \mathrm{~N}$

$\delta^{34} \mathrm{~S}$ from samples of $J$. edwardsii from Inner Doubtful Sound resolved the relative contributions of forest litter and chemoautotrophs (Fig. 4B). For this region, 100\% of the recycled carbon source could be attributed to chemoautotrophs, which made up $28 \pm 0.02 \%$ (mean \pm SE) of the total diet (Fig. 4B).
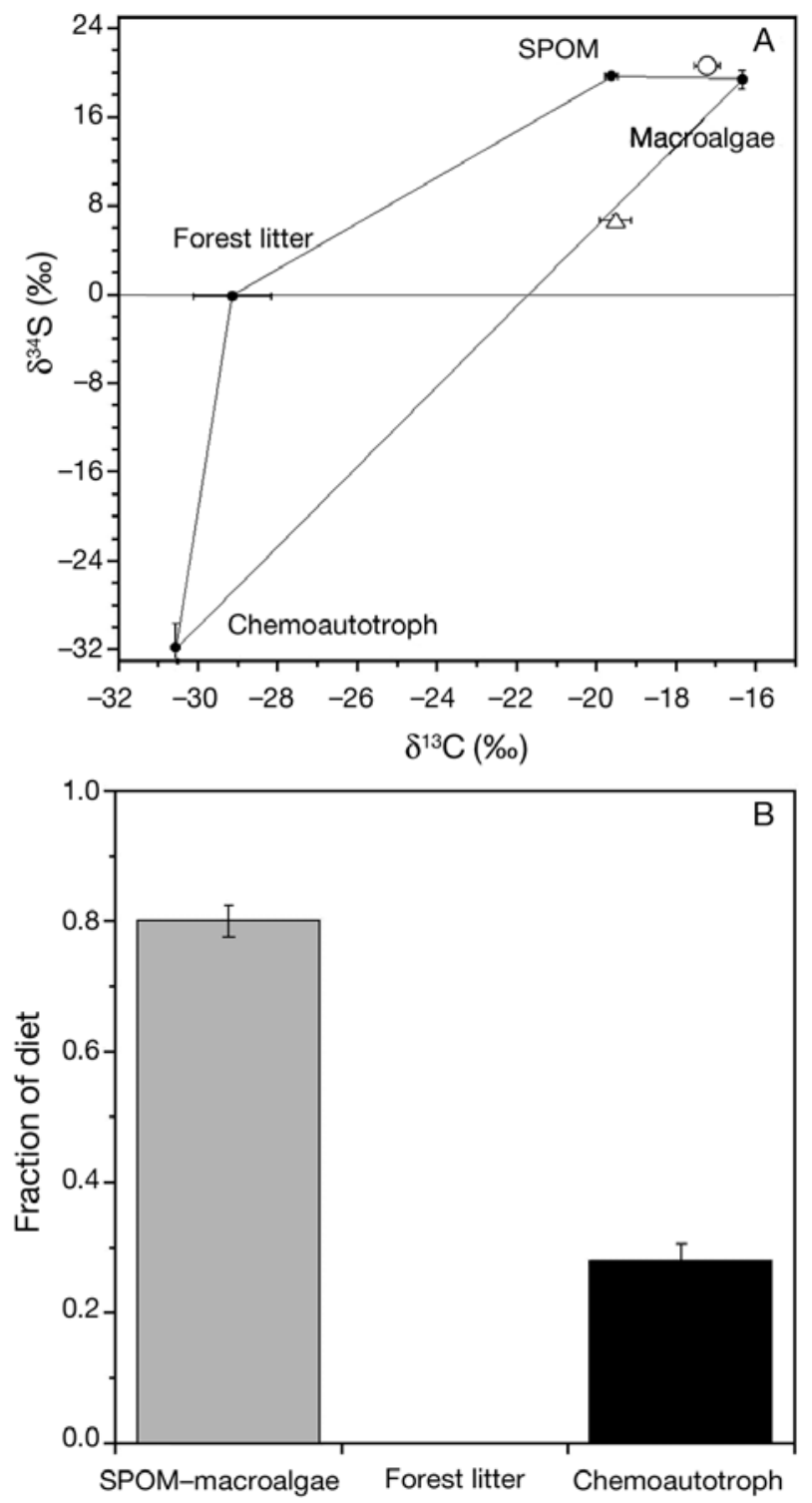

Fig. 4. Jasus edwardsii. (A) $\delta^{13} \mathrm{C}$ and $\delta^{34} \mathrm{~S}$ for red rock lobsters from Taipari Roa Reserve and inner Doubtful Sound $(\Delta)$ and from the entrance of Doubtful Sound $(O)$, and for primary carbon sources $(\bullet)$ (chemoautotroph, forest litter, suspended particulate organic matter [SPOM] and macroalgae) showing mean and SE. (B) Relative proportions of carbon sources (SPOM-macroalgae, forest litter and chemoautotroph) used by lobsters from Taipari Roa Reserve and inner Doubtful Sound from the Isoerror mixing model using $\delta^{13} \mathrm{C}$ and $\delta^{34} \mathrm{~S}$

\section{FA concentration and $\delta^{13} \mathrm{C}$}

The FAs with the highest concentrations measured in Jasus edwardsii muscle tissue were the saturated compounds $16: 0$ and 18:0, and the monounsaturated

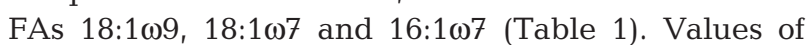
$\delta^{13} \mathrm{C}$ were obtained for these compounds and for 20:1 $\omega 9$ for individuals from all 3 regions (Table 1). For 
Table 1. Jasus edwardsii. Relative concentration (mean $\pm 1 \mathrm{SE}$ ) and values of $\delta^{13} \mathrm{C}$ of fatty acid components in red rock lobster muscle tissue. DS: Doubtful Sound

\begin{tabular}{|c|c|c|c|c|c|c|}
\hline \multirow[t]{2}{*}{ Compound } & \multirow[b]{2}{*}{$\begin{array}{c}\text { Te Awaatu } \\
\quad(\mathrm{n}=3)\end{array}$} & \multirow{2}{*}{$\begin{array}{l}\text { Relative concentration } \\
\text { Taipari Roa + inner DS } \\
\qquad(\mathrm{n}=3)\end{array}$} & \multirow[b]{2}{*}{$\begin{array}{c}\text { Kuta Parera } \\
\qquad(\mathrm{n}=2)\end{array}$} & \multicolumn{3}{|c|}{$-\delta^{13} \mathrm{C}(\%)$ of fatty acid component- } \\
\hline & & & & $\begin{array}{l}\text { Te Awaatu } \\
\quad(\mathrm{n}=3)\end{array}$ & $\begin{array}{l}\text { Taipari Roa + inner DS } \\
\qquad(\mathrm{n}=3)\end{array}$ & $\begin{array}{c}\text { Kuta Parera } \\
\quad(\mathrm{n}=2)\end{array}$ \\
\hline 16:0 & $31.24 \pm 4.04$ & $25.76 \pm 1.23$ & 25.46 & $-21.73 \pm 0.32$ & $-25.78 \pm 0.73$ & -22.7 \\
\hline $16: 1 \omega 7$ & $10.20 \pm 1.65$ & $11.42 \pm 1.29$ & 11.20 & $-23.68 \pm 0.57$ & $-30.65 \pm 1.40$ & -22.1 \\
\hline 18:0 & $17.76 \pm 2.76$ & $20.51 \pm 1.30$ & 20.05 & $-18.58 \pm 0.58$ & $-22.78 \pm 0.50$ & -21.6 \\
\hline 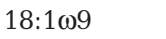 & $30.41 \pm 5.07$ & $23.86 \pm 2.06$ & 28.38 & $-24.58 \pm 0.47$ & $-28.36 \pm 0.83$ & -21.9 \\
\hline $18: 1 \omega 7$ & $7.92 \pm 0.90$ & $14.58 \pm 2.63$ & 10.88 & $-34.47 \pm 2.28$ & $-34.03 \pm 1.07$ & -26.1 \\
\hline 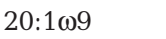 & $2.46 \pm 0.48$ & $3.88 \pm 1.29$ & 4.02 & $-24.16 \pm 0.07$ & $-34.58 \pm 2.01$ & -25.6 \\
\hline 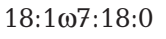 & $0.45: 1$ & $0.71: 1$ & $0.54: 1$ & & & \\
\hline Average & & & & $-24.53 \pm 1.23$ & $-29.36 \pm 1.11$ & $-23.1 \pm 0.57$ \\
\hline
\end{tabular}

all FA compounds (excluding 18:1 $\omega 7$ ), $\delta^{13} \mathrm{C}$ was more depleted in ${ }^{13} \mathrm{C}$ at inner Doubtful Sound than at Te Awaatu Channel and Kuta Parera Reserve, with the mean value of $\delta^{13} \mathrm{C}$ for the 6 components being $>4 \%$ lower at inner Doubtful Sound. Low values of $\delta^{13} \mathrm{C}$ were found for 18:1 107 at Te Awatu Channel and inner Doubtful Sound (ca. -34\%o). This FA was present in higher quantities in lobsters from inner Doubtful Sound than in those from the other 2 regions. The ratio of 18:1 1 7 to 18:0 was higher for inner Doubtful Sound lobsters $(0.71: 1)$ than for those from Te Awaatu Channel $(0.45: 1)$ and Kuta Parera Reserve (0.54:1). Low values of $\delta^{13} \mathrm{C}$ (less than $-30 \%$ ) were also found for the

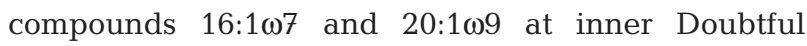
Sound.

\section{DISCUSSION}

The results of this study demonstrate that the efficacy of marine protected areas for supporting predators, such as red rock lobsters, may be strongly influenced by bottom-up forcing on habitat quality and availability of prey. In this example, the effects of low salinity exposure on bivalve abundance (Tallis et al. 2004, McLeod \& Wing 2008) and infaunal community composition (Rutger \& Wing 2006) have altered the available diet and basal source of organic carbon to food webs supporting the invertebrate predator Jasus edwardsii, which appears to have influenced its abundance and distribution.

Results of a mass balance model using $\delta^{13} \mathrm{C}$ and $\delta^{15} \mathrm{~N}$ of primary carbon sources (macroalgae, SPOM and combined forest litter and chemoautotrophs) indicate that, in marine reserves where heterotrophic bivalve food resources are abundant, much of the resource base for lobsters is new production derived from SPOM and macroalgae. However, in the inner regions of Doubtful Sound where heterotrophic bivalves are scarce, the base of the food web becomes more reliant on recycled carbon from forest litter and/or chemoautotrophs. A 2nd mixing model using $\delta^{34} \mathrm{~S}$ resolved the relative contributions of forest litter and chemoautotrophs to red rock lobsters for this region. Results from this model indicate that chemoautotrophs contribute up to $28 \pm 0.02 \%$ of the diet of red rock lobsters in inner Doubtful Sound with no evidence for direct use of forest litter carbon. Values of $\delta^{34} \mathrm{~S}$ derived from sea water sulfate $(\sim 18 \%)$, terrestrial sulfate $(\sim 0 \%)$ and $\mathrm{H}_{2} \mathrm{~S}$ in reducing sediments (ca. -20\%) (Peterson \& Fry 1987) are markedly different and there is relatively little fractionation associated with trophic level for this element (Canfield 2001, McCutchan et al. 2003), making it a valuable discriminator of these carbon sources.

Results from analysis of $\delta^{13} \mathrm{C}, \delta^{15} \mathrm{~N}$ and $\delta^{34} \mathrm{~S}$ of red rock lobster muscle relative to the primary carbon sources are corroborated by analysis of compoundspecific $\delta^{13} \mathrm{C}$, specifically the unsaturated FAs 16:1 107

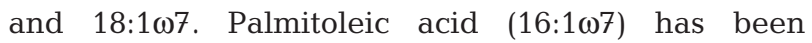
employed widely as a specific biomarker for microbial activity, particularly chemoautotrophic production (MacAvoy et al. 2002a,b) but it may also originate from diatoms (Lewis 1969, Pond et al. 1998) or be biosynthesized from other compounds. The $\delta^{13} \mathrm{C}$ signature of $16: 1 \omega 7$ from sulfur-oxidizing bacteria is typically in the range of -28 to $-35 \%$, while 16:1 107 sourced from phytoplankton is more ${ }^{13} \mathrm{C}$ enriched (Pond et al. 1997). In the present study, we observed that 16:107 from red rock lobster mussel tissue was relatively more depleted in ${ }^{13} \mathrm{C}$ in inner Doubtful Sound $\left(\delta^{13} \mathrm{C}-30.65 \pm\right.$ $1.40 \%$, mean $\pm \mathrm{SE})$ than at Te Awaatu Channel $\left(\delta^{13} \mathrm{C}\right.$ $-23.68 \pm 0.57 \%$ o $)$ and at Kuta Parera Reserve $\left(\delta^{13} \mathrm{C}\right.$ $-22.1 \%$ ). This pattern is consistent with a chemoautotrophic microbial source of 16:1 107 in inner Doubtful Sound such as the common symbiont-bearing clam Solemya parkinsonii (Fainer \& Wadley 1991, McLeod \& Wing 2007, Rodgers \& Wing 2008). At Te Awaatu Channel and within Kuta Parera Reserve, results are consistent with a marine algal-based source, such as that assimilated by the abundant filter-feeding bivalve 
Mytilus edulis galloprovincialis and the less abundant Perna canaliculus and Aulacomya atra maoriana.

A similar pattern was observed in cis-vaccenic acid $(18: 1 \omega 7)$, which is also used as a microbial biomarker (Conway \& McDowell Capuzzo 1991, MacAvoy et al. 2002b, McLeod \& Wing 2007). This compound was present in lower concentrations at the fjord entrance sites than in samples taken from inner Doubtful Sound, but both were depleted in ${ }^{13} \mathrm{C}$ (Te Awaatu Channel: $\delta^{13} \mathrm{C}$ $-34.47 \pm 2.28 \%$, inner Doubtful Sound: $\delta^{13} \mathrm{C}-34.03 \pm$ 1.07), which is consistent with contributions from chemoautotrophic bacteria. At the Kuta Parera Reserve sites, values of $\delta^{13} \mathrm{C}$ of $18: 1 \omega 7$ were more enriched in ${ }^{13} \mathrm{C}$, which is consistent with a proportion of this component being biosynthesized from the saturated 18:0 FA pool, or originating from heterotrophic microbial pathways. Marine fauna that obtain a high proportion of their nutrition from chemoautotrophic bacteria tend to have a high ratio in the amount of 18:107 to 18:0 (e.g. Solemya parkinsonii 4.57:1; McLeod \& Wing 2007). Jasus edwardsii from inner Doubtful Sound had a higher ratio of these 2 compounds than those from the other sites (Table 1). These patterns are consistent with more reliance of inner Doubtful Sound populations of lobsters on chemoautotrophic production, while those from the other sites more consistently used new production carbon sources (macroalgae and phytoplankton), as indicated by the mass balance models using $\delta^{13} \mathrm{C}, \delta^{15} \mathrm{~N}$ and $\delta^{34} \mathrm{~S}$ of muscle tissue.

This shift toward more recycled production in the food web supporting Jasus edwardsii that inhabit inner Doubtful Sound corresponds with a significantly lower abundance of red rock lobsters across the region including in the Taipari Roa Marine Reserve. The increased reliance of red rock lobsters on recycled production in inner Doubtful Sound indicates that the routing of carbon in the food web and the basis for productivity differs between regions in the Doubtful-Bradshaw Sound complex and that there are likely differences in the productivity, availability and quality of food sources between regions. The low salinity layer in Doubtful Sound provides a refuge from predation for Mytilus edulis galloprovincialis, an important component of the diet of $J$. edwardsii (Witman \& Grange 1998). In this case, the mussel beds are protected from predation by stenohaline species but provide an important input into the marine food web during times when the low salinity layer thins and when mussels are dislodged from the beds (Witman \& Grange 1998). Conversely, in inner Doubtful Sound, bivalves are exposed to more prolonged freshwater inputs, and shallow water populations of infaunal and epibenthic bivalves are largely depleted (Rutger \& Wing 2006, McLeod \& Wing 2008). Here a shift toward reliance on infaunal invertebrate prey bearing chemosynthetic bacteria likely incurs an energetic cost of foraging, as they are deeply buried and occur in deeper habitat and at low densities relative to mussels (Brewin et al. 2008). This is likely reflected in the low abundance of red rock lobsters at these sites.

While the results of this study suggest a possible causal relationship between the carbon sources to food available to red rock lobsters and red rock lobster abundance in the marine reserves, several alternative hypotheses must be considered. Larger no-take zones have been demonstrated to harbor higher densities of commercial species. Positive reserve effects may also be linked to the time elapsed since establishment (Claudet et al. 2008). These 2 factors, perhaps in combination with habitat effects, may explain the observed differences in lobster abundance at Te Awaatu Reserve (87 ha, est. 1993) and Taipari Roa marine reserve (610.8 ha, est. 2005). However, they cannot explain the relatively high density of lobsters found at Kuta Parera Reserve, which is roughly two-thirds the size of the Taipari Roa Reserve and was established at the same time.

The inner reaches of Doubtful Sound are accessible from the land. It is therefore possible that the abundance patterns we observed in the present study reflect a difference in fishing pressure between regions. However, the inner regions of both Bradshaw and Doubtful Sounds have sustained similar historical fishing pressure, so differences in fishing pressure cannot explain the differences observed at these 2 sites. The observed pattern in red rock lobster abundance may also be related to the physical habitat structure in each region. Red rock lobsters are typically found in crevices and caves (MacDiarmid 1991, Annala \& Bycroft 1993), are generally patchily distributed and may take up longterm residency associated with rocky reefs, where they are important predators on invertebrates (Kelly 2001, Langlois et al. 2005). This is not a likely explanation for the observed patterns, since each survey site contains large areas of suitable habitat in terms of the physical structure. In the inner reaches of Doubtful Sound, extended periods of freshwater input from rain and the Manapouri power plant result in low salinity events to depths up to 10 to $12 \mathrm{~m}$ (Rutger \& Wing 2006). This periodic direct exposure to low salinity water may prevent establishment of resident red rock lobsters in this depth zone. Nevertheless, we observed red rock lobsters that have been resident for $>3 \mathrm{yr}$ at $15 \mathrm{~m}$ depth, on some rock walls in inner Doubtful Sound (L. Jack unpubl. data). The most likely explanation for the low abundance of red rock lobsters at Taipari Roa marine reserve remains insufficient food due to the reduction in heterotrophic bivalves in the region.

In the present study, we obtained clear evidence for differences in carbon sources to food webs supporting red rock lobster populations inhabiting 3 marine 
reserves. The effects of habitat conversion and loss of bivalves in inner Doubtful Sound are apparent in a distinct shift in the food web to recycled carbon sources, particularly chemoautotrophs. These results demonstrate the pivotal role of heterotrophic bivalves for carbon routing in this system and how physical alterations to habitat quality has had ecosystem level consequences. The resultant reduction of benthic-pelagic coupling and low abundance of red rock lobster populations at Taipari Roa is unlikely to be ameliorated by a reduction in fishing pressure. Reserve implementation at this locality is therefore less likely to be effective in restoring fished stocks or biodiversity than at other locations with more intact food webs. The strong ecological gradients in Fiordland and the network of reserves nested within this landscape provide a testing ground for assessing the effects of implementing marine reserves on whole food webs within isolated habitat patches. The present study provides a clear example of how differences in habitat quality should be considered for the effective conservation of functional food webs and so in the judicious application of marine reserves.

Acknowledgements. We thank R. Frew, T. Benbow, E. Green, K. Blakemore, P. Young, K. Clark, J. Leichter, S. Rutger, and the Departments of Marine Science and Chemistry at University of Otago for assistance with this work. Monetary and logistic support was provided from the Royal Society of New Zealand's Marsden Fund to S.R.W. (UO-00213), a Bright Futures Scholarship to R.J.M. and a Commonwealth Scholarship to L.J.

\section{LITERATURE CITED}

Allison GW, Lubchenco J, Carr MH (1998) Marine reserves are necessary but not sufficient for marine conservation. Ecol Appl 8(Suppl 1):S79-S92

Almany GR, Berumen ML, Thorrold SR, Planes S, Jones GP (2007) Local replenishment of coral reef fish populations in a marine reserve. Science 316:742-744

Annala JH (1983) New Zealand rock lobsters: biology and fishery. Fisheries Research Division occasional publication no. 42. New Zealand Ministry of Agriculture and Fisheries, Wellington

Annala JH, Bycroft BL (1993) Movements of rock lobsters (Jasus edwardsii) tagged in Fiordland, New Zealand. N Z J Mar Freshw Res 27:183-190

Batham E (1965) Rocky shore ecology of a southern New Zealand fjord. Trans R Soc N Z 6:215-227

Bligh EG, Dyer WJ (1959) A rapid method of total lipid extraction and purification. Can J Biochem Physiol 37:911-917

Bohnsack J (1996) Maintenance and recovery of reef fishery productivity. In: Poulinin N, Roberts C (eds) Reef fisheries. Chapman \& Hall, London, p 283-313

Botsford LW, Hastings A, Gaines SD (2001) Dependence of sustainability on the configuration of marine reserves and larval dispersal distance. Ecol Lett 4:144-150

Boyle MC, Jillett JB, Mladenov PV (2001) Intertidal communities in Doubtful Sound, New Zealand: changes over time. N Z J Mar Freshw Res 35:663-673
Brewin PE, Probert PK, Barker MF (2008) Deep-basin macrobenthos of Doubtful Sound, Fiordland, New Zealand. N Z J Mar Freshw Res 42:1-21

Canfield DE (2001) Biogeochemistry of sulfur isotopes. Rev Mineral Geochem 43:607-636

Claudet J, Osenberg CW, Benedetti-Cecchi L, Domenici P and others (2008) Marine reserves: size and age do matter. Ecol Lett 11:481-489

Conway N, McDowell Capuzzo J (1991) Incorporation and utilization of bacterial lipids in the Solemya velum symbiosis. Mar Biol 108:277-291

Cowen RK, Lwiza KMM, Spongaugle S, Paris CB, Olson DB (2000) Connectivity of marine populations: open or closed? Science 287:857-859

Fainer SF, Wadley VA (1991) Abundance, growth and production of the bivalve Solemya sp., a food source for juvenile rock lobsters in a seagrass community in Western Australia. J Exp Mar Biol Ecol 152:201-223

Fleishman E, Ray C, Sjögren-Gulve P, Boggs CL, Murphy DD (2002) Assessing the roles of patch quality, area, and isolation in predicting metapopulation dynamics. Conserv Biol 16:706-716

Fogarty MJ (1999) Essential habitat, marine reserves and fishery management. Trends Ecol Evol 14:133-134

Fogarty MJ (1998) Implications of migration and larval interchange in American lobster (Homarus americanus) stocks: spatial structure and resilience. In: Jamieson GS, Campbell A (eds) Proc North Pacific Symp Invertebrate Stock Assessment and Management, Naniamo, Mar 6-10, 1995. NRC Research Press, Ottawa, p 273-283

Francis MP, Hardy GS, Ward C, Williams MW (1989) Survey of Fiordland reef fish populations 1986-1987. University of Auckland, Auckland

Franklin AB, Anderson DR, Gutierrez RJ, Burnham KP (2000) Climate, habitat quality, and fitness in northern spotted owl populations in northwestern California. Ecol Monogr 70:539-590

> Goebel NL, Wing SR, Boyd PW (2005) A mechanism for onset of diatom blooms in a fjord with persistent salinity stratification. Estuar Coast Shelf Sci 64:546-560

> Halpern BS (2003) The impact of marine reserves: do reserves work and does reserve size matter? Ecol Appl 13(Suppl): $117-137$

Hanski I, Gaggiotti OE (2004) Ecology, genetics, and evolution of metapopulations. Elsevier Academic Press, Amsterdam

Hanski I, Gyllenberg M (1993) Two general metapopulation models and the core-satellite species hypothesis. Am Nat 142:17-41

Jeffries M (2005) Local-scale turnover of pond insects: intrapond habitat quality and inter-pond geometry are both important. Hydrobiologia 543:207-220

Joy MK, Death RG (2001) Control of freshwater fish and crayfish community structure in Taranaki, New Zealand: dams, diadromy or habitat structure? Freshw Biol 46:417-429

Kelly S (2001) Temporal variation in the movement of the spiny lobster Jasus edwardsii. Mar Freshw Res 52: 323-331

Lamare MD (1998) Origin and transport of larvae of the sea urchin Evechinus chloroticus (Echinodermata: Echinoidea) in a New Zealand fjord. Mar Ecol Prog Ser 174: $107-121$

Langlois TJ, Anderson MJ, Babcock RC (2005) Reefassociated predators influence adjacent soft-sediment communities. Ecology 86:1508-1519

Lewis RW (1969) The fatty acid composition of Arctic marine phytoplankton and zooplankton with special reference to minor acids. Limnol Oceanogr 14:35-40 
Lindholm JB, Auster PJ, Ruth M, Kaufman L (2001) Modeling the effects of fishing and implications for the design of marine protected areas: juvenile fish responses to variations in seafloor habitat. Conserv Biol 15:424-437

Lusseau SM, Wing SR (2006) Importance of local production versus pelagic subsidies in the diet of an isolated population of bottlenose dolphins Tursiops sp. Mar Ecol Prog Ser 321:283-293

MacArthur RH, Wilson EO (1967) The theory of island biogeography. Princeton University Press, Princeton, NJ

MacAvoy SE, Carney RS, Fisher CR, Macko SA (2002a) Use of chemosynthetic biomass by large, mobile, benthic predators in the Gulf of Mexico. Mar Ecol Prog Ser 225: 65-78

MacAvoy SE, Macko SA, Joye SB (2002b) Fatty acid carbon isotope signatures in chemosynthetic mussels and tube worms from Gulf of Mexico hydrocarbon seep communities. Chem Geol 185:1-8

MacDiarmid AB (1991) Seasonal changes in depth distribution, sex ratio and size frequency of spiny lobster Jasus edwardsii on a coastal reef in northern New Zealand. Mar Ecol Prog Ser 70:129-141

> McClanahan TR, Mangi S (2000) Spillover of exploitable fishes from a marine park and its effect on the adjacent fishery. Ecol Appl 10:1792-1805

McCutchan JH Jr, Lewis WM, Kendall C, McGrath CC (2003) Variation in trophic shift for stable isotope ratios of carbon, nitrogen, and sulfur. Oikos 102:378-390

McLeod RJ, Wing SR (2007) Hagfish in the New Zealand fjords are supported by chemoautotrophy of forest carbon. Ecology 88:809-816

$>$ McLeod RJ, Wing SR (2008) Influence of an altered salinity regime on the population structure of two infaunal bivalve species. Estuar Coast Shelf Sci 78:529-540

NRC (National Research Council) (2001) Marine protected areas: tools for sustaining ocean ecosystems. National Academy Press, Washington, DC

Palumbi SR (2001) The ecology of marine protected areas. In: Bertness MD, Gaines SS, Hay ME (eds) Marine community ecology. Sinauer Associates, Sunderland, p 509-530

Pande A, MacDiarmid AB, Smith PJ, Davidson RJ and others (2008) Marine reserves increase the abundance and size of blue cod and rock lobster. Mar Ecol Prog Ser 366: $147-158$

Perrin C, Wing SR, Roy MS (2004) Effects of hydrographic barriers on population genetic structure of the sea star Coscinasterias muricata (Echinodermata, Asteroidea) in the New Zealand fjords. Mol Ecol 13:2183-2195

Peterson BJ, Fry B (1987) Stable isotopes in ecosystem studies. Annu Rev Ecol Syst 18:293-320

Phillips DL, Gregg JW (2001) Uncertainty in source partitioning using stable isotopes. Oecologia 127:171-179

Pond DW, Segonzac M, Bell MV, Dixon DR, Fallick AE, Sargent JR (1997) Lipid and lipid carbon stable isotope composition of the hydrothermal vent shrimp Mirocaris fortunata: evidence for nutritional dependence on photosynthetically fixed carbon. Mar Ecol Prog Ser 157: 221-231

Pond DW, Bell MV, Harris RP, Sargent JR (1998) Microplanktonic polyunsaturated fatty acid markers: a mesocosm trial. Estuar Coast Shelf Sci 46:61-67

Quinn JF, Wing SW, Botsford LW (1993) Harvest refugia in marine invertebrate fisheries: models and applications to the red sea urchin, Strongylocentrotus franciscanus. Am Zool 33:537-550
Roberts CM, Bohnsack JA, Gell F, Hawkins JP, Goodridge R (2001) Effects of marine reserves on adjacent fisheries. Science 294:1920-1923

> Roberts CM, Branch G, Bustamante RH, Castilla JC and others (2003) Application of ecological criteria in selecting marine reserves and developing reserve networks. Ecol Appl 13(Suppl):215-228

Rodgers KL, Wing SR (2008) Spatial structure and movement of blue cod Parapercis colias in Doubtful Sound, New Zealand, inferred from $\delta^{13} \mathrm{C}$ and $\delta^{15} \mathrm{~N}$. Mar Ecol Prog Ser 359:239-248

Rodwell LD, Barbier EB, Roberts CM, McClanahan TR (2003) The importance of habitat quality for marine reserves-fishery linkages. Can J Fish Aquat Sci 60:171-181

Root KV (1998) Evaluating the effects of habitat quality, connectivity, and catastrophes on a threatened species. Ecol Appl 8:854-865

$>$ Rutger SM, Wing SR (2006) Effects of freshwater input on shallow-water infaunal communities in Doubtful Sound, New Zealand. Mar Ecol Prog Ser 314:35-47

> Sanford E, Menge BA (2007) Reproductive output and consistency of source populations in the sea star Pisaster ochraceus. Mar Ecol Prog Ser 349:1-12

Shears NT, Babcock RC (2002) Marine reserves demonstrate top-down control of community structure on temperate reefs. Oecologia 132:131-142

Sköld M, Wing SR, Mladenov PV (2003) Genetic subdivision of a sea star with high dispersal capability in relation to physical barriers in a fjordic seascape. Mar Ecol Prog Ser 250:163-174

Smith F (2001) Historical regulation of local species richness across a geographic region. Ecology 82:792-801

Suring E, Wing SR (2009) Isotopic turnover rate and fractionation in multiple tissues of red rock lobster (Jasus edwardsii) and blue cod (Parapercis colias): consequences for ecological studies. J Exp Mar Biol Ecol 370:56-63

Tallis HM, Wing SR, Frew RD (2004) Historical evidence for habitat conversion and local population decline in a New Zealand fjord. Ecol Appl 14:546-554

Thorrold SR, Latkoczy C, Swart PK, Jones CM (2001) Natal homing in a marine fish metapopulation. Science 291: 297-299

Warner RR, Cowen RK (2002) Local retention of production in marine populations: evidence, mechanisms, and consequences. Bull Mar Sci 70:245-249

Wing SR (2009) Decadal scale dynamics of sea urchin population networks in Fiordland, New Zealand are driven by juxtaposition of larval transport against benthic productivity gradients. Mar Ecol Prog Ser 378:125-134

Wing SR, Gibbs MT, Lamare MD (2003) Reproductive sources and sinks within a sea urchin, Evechinus chloroticus, population of a New Zealand fjord. Mar Ecol Prog Ser 248: 109-123

Wing SR, Leichter JJ, Perrin C, Rutger SM, Bowman MH, Cornelisen CD (2007) Topographic shading and wave exposure influence morphology and ecophysiology of Ecklonia radiata (C. Agardh 1817) in Fiordland, New Zealand. Limnol Oceanogr 52:1853-1864

Wing SR, McLeod RJ, Clark KL, Frew RD (2008) Plasticity in the diet of two echinoderm species across an ecotone: microbial recycling of forest litter and bottom-up forcing of population structure. Mar Ecol Prog Ser 360: 115-123

Witman JD, Grange KR (1998) Links between rain, salinity, and predation in a rocky subtidal community. Ecology 79:2429-2447 